\title{
SISTEM PENGAMBILAN KEPUTUSAN PENERIMA BEASISWA DI SMKN 4 JENEPONTO DENGAN MENGGUNAKAN METODE WEIGHTED PRODUCT
}

\author{
Syamsumarlin Taha', Tamus Bin Tahir ${ }^{2}$ \\ Dosen Fakultas Teknik Dan Informatika, Universitas Patria Artha 1,2 \\ syamsumarlintaha@gmail.com ${ }^{1}$, tamusbintahir@gmail.com²
}

\begin{abstract}
ABSTRAK
Penelitian ini bertujuan untuk merancang aplikasi sistem pengambilan keputusan penerima beasiswa di SMKN 4 Jeneponto dengan menngunakan metode Weighted Product untuk menentukan penerima beasiswa dulunya masih menggunakan cara manual menjadi terkomputerisasi. Hasil uji coba pembuatan aplikasi yang dilakukan peneliti dengan menggunakan metode uji kelayakan aplikasi ISO 9126 dengan hasil dan fungsifungsi dalam aplikasi sistem pengambilan keputusan penerima beasiswa telah berfungsi dengan benar dan sesuai yang diharapkan, sedangkan hasil uji coba diperoleh kesimpulan bahwa sikap tiap responden terhadap kualitas aplikasi sistem pengambilan keputusan penerima beasiswa adalah baik, ini dapat dilihat dari validasi yang telah dilakukan dan menyimpulkan bahwa kualitas sistem ini baik dan layak digunakan.
\end{abstract}

\section{Kata Kunci-Sistem Pengambilan Keputusan, Weighted Product.}

\section{I.PENDAHULUAN}

Menyadari bahwa pendidikan sangat penting, negara sangat mendukung setiap warga negaranya untuk meraih pendidikan setinggi-tingginya. Beberapa di antaranya melakukan program pendidikan gratis dan program beasiswa. akan tetapi pemerintah, perusahaan swasta, kedutaan, universitas, serta lembaga pendidik atau peneliti. Biaya tersebut diberikan kepada yang berhak menerima sesuai dengan kriteria yang ditentukan.

Setiap lembaga pendidikan khususnya Sekolah Menengah Atas (SMA) maupun Sekolah Menengah Kejuruan (SMK) pada umumnya memiliki suatu program pendidikan, yaitu pemberian beasiswa kepada siswa yang berprestasi, maupun kepada siswa yang tidak mampu. Demikian halnya dengan SMK Negeri 4 Jeneponto yang telah memiliki program pemberian beasiswa terhadap siswa-siswanya. Beasiswa harus diberikan kepada penerima yang layak dan pantas untuk mendapatkannya. Akan tetapi, dalam melakukan seleksi beasiswa tersebut tentu akan mengalami kesulitan karena banyaknya pengaju beasiswa dan adanya beberapa kriteria yang digunakan untuk menentukan siapa penerima beasiswa yang sesuai dengan yang diharapkan. Sebab calon penerima beasiswa hanya yang memenuhi seluruh komponen beasiswa. 
Volume 2 Nomor. 2, Oktober 2017

P -ISSN : 2541-1179, E-ISSN : 2581-1711

OJS :http://journal.uin-alauddin.ac.id/index.php/instek/index

INFORIATIKASANS DAN TERNOLOGI

Email : instek@uin-alauddin.ac.id

Permasalahan yang sering muncul yaitu kurang tepatnya penyaluran beasiswa terhadap siswa, misalnya siswa yang tidak berhak mendapatkan beasiswa namun mendapatkan beasiswa, dan sebaliknya siswa yang seharusnya mendapatkan beasiswa tetapi tidak mendapatkan beasiswa, baik itu beasiswa prestasi ataupun beasiswa tidak mampu. Masalah seperti itu muncul dikarenakan kurang telitinya para penyeleksi beasiswa dalam melakukan seleksi penerima beasiswa, hal ini disebabkan pihak penyeleksi beasiswa itu sendiri para guru yang ada di SMK Negeri 4 Jeneponto yang pekerjaannya mengajar para siswa, sehingga kurangnya waktu yang dibutuhkan untuk melakukan penyeleksian penerima beasiswa. Ada beberapa kasus yang pernah terjadi beberapa diantaranya yang terjadi pada tahun 2015 bulan oktober yaitu adanya beberapa siswa yang dianggap kurang mampu dan berhak mendapatkan beasiswa tetapi tidak mendapatkan beasiswa sebab adanya kekeliruan pada saat proses penyeleksian beasiswa.

Berdasarkan permasalahan tersebut diatas maka dipandang perlu untuk mengembangan Sistem Pendukung pengambilan Keputusan yang akurat sehingga dapat membantu dan mempermudah proses pengambilan keputusan. Decision support systems (DSS) merupakan sebuah bagian dari sistem informasi yang telah banyak diterapkan untuk memudahkan pengambilan keputusan baik untuk jangka pendek, menengah, ataupun panjang. Penelitian ini menggunakan meotode Weighted Product, yaitu salah satu metode penyelesaian pada masalah MADM. Metode ini mengevaluasi beberapa alternatif terhadap sekumpulan atribut atau kriteria, dimana setiap atribut saling tidak bergantung satu dengan yang lainnya. Metode Weighted Product menggunakan tekhnik perkalian untuk menghubungkan rating atribut, dimana rating tiap atribut harus dipangkatkan terlebih dahulu dengan bobot atribut yang bersangkutan. Proses ini sama halnya dengan proses normalisasi.

\section{METODE PENELITIAN}

Penelitian ini merupakan penelitian Pengembangan Perangkat Lunak (Software Development). Penelitian ini akan disajikan berupa sistem informasi yang berbasis web dengan objeknya yaitu sistem pengambilan keputusan penerima beasiswa. 
Volume 2 Nomor. 2, Oktober 2017

P-ISSN : 2541-1179, E-ISSN : 2581-1711

OJS :http://journal.uin-alauddin.ac.id/index.php/instek/index

INFORIATIKASANS DAN TERNOLOG

Email : instek@uin-alauddin.ac.id

\section{A. Analisis Kebutuhan Sistem}

Dalam membangun sistem FMADM ini, data input yang dibutuhkan untuk memenuhi kriteria yang dijadikan sebagai faktor dalam menentukan penerima beasiswa. Kriteria tersebut antara lain adalah:

1. Nilai rata-rata rapor.

Kriteria nilai rapor merupakan persyaratan yang ditentukan untuk pengambilan keputusan, berdasarkan nilai rapor yang diperoleh oleh siswa selama studi berlangsung.

Tabel 1.Tabel konversi nilai Kriteria Nilai Rapor

\begin{tabular}{|c|c|}
\hline Kriteria & Variabel \\
\hline $60<\mathrm{IPK}<70$ & Sangat Rendah \\
\hline $70<\mathrm{IPK}<80$ & Rendah \\
\hline $80<\mathrm{IPK}<90$ & Tinggi \\
\hline $\mathrm{IPK}>90$ & Sangat Tinggi \\
\hline
\end{tabular}

2. Pengahasilan Orang Tua.

Kriteria penghasilan orangtua merupakan persyaratan yang ditentukan untuk pengambilan keputusan, berdasarkan jumlah penghasilan bulanan baik itu penghasilan tetap maupun tidak tetap pada tabel berikut:

Tabel 2. Tabel konversi nilai Kriteria Penghasilan Orang Tua

\begin{tabular}{|l|l|}
\hline \multicolumn{1}{|c|}{ Kriteria } & \multicolumn{1}{c|}{ Variabel } \\
\hline Penghasilan $<1$ jt & Sangat tinggi \\
\hline $\begin{array}{l}\text { Penghasilan } 1 \text { jt s.d }< \\
2,5 \text { jt }\end{array}$ & Tinggi \\
\hline $\begin{array}{l}\text { Penghasilan 2,5 jt s.d }< \\
5 \text { jt }\end{array}$ & Rendah \\
\hline Penghasilan $>5$ jt & Sangat Rendah \\
\hline
\end{tabular}

3. Jumlah Bersaudara.

Kriteria Jumlah Bersaudara. Kriteria jumlah bersaudara merupakan persyaratan yang ditentukan untuk pengambilan keputusan, serta jumlah anak yang masih menjadi tanggung jawab orangtua untuk memenuhi biaya hidup pada tabel berikut: 
Volume 2 Nomor. 2, Oktober 2017

P -ISSN : 2541-1179, E-ISSN : 2581-1711

OJS :http://journal.uin-alauddin.ac.id/index.php/instek/index

MFORIATIKASANIS DAN TERNOLOG

Email : instek@uin-alauddin.ac.id

Tabel 3. Tabel konversi nilai Kriteria Jumlah Bersaudara

\begin{tabular}{|l|c|}
\hline \multicolumn{1}{|c|}{ Kriteria } & Variabel \\
\hline Tanggungan 1 & Sangat Rendah \\
\hline Tanggungan 2 & Rendah \\
\hline Tanggungan 3 & Tinggi \\
\hline $\begin{array}{l}\text { Tanggungan }>3 \\
\text { Orang }\end{array}$ & Sangat Tinggi \\
\hline
\end{tabular}

4. Jarak Tempuh Rumah dengan Sekolah

Jarak tempuh rumah dengan sekolah merupakan persyaratan yang ditentukan untuk pengambilan keputusan, berdasarkan jarak tempuh serta waktu tempuh oleh siswa untuk sampai disekolah.

Tabel 4. Tabel konversi Jarak Tempuh Rumah dengan Sekolah

\begin{tabular}{|c|c|}
\hline Kriteria & Variabel \\
\hline $1-5 \mathrm{Km}$ & Sangat Rendah \\
\hline $6-10 \mathrm{Km}$ & Rendah \\
\hline $11-15 \mathrm{Km}$ & Tinggi \\
\hline$>16 \mathrm{Km}$ & Sangat Tinggi \\
\hline
\end{tabular}

\section{B. Instrumen Penelitian}

Angket atau kuesioner merupakan alat pengambilan informasi dari informan kepada peneliti yang memuat sejumlah data. Kuesioner ini dapat menggambarkan bebebrapa hal terkait materi yang akan diteliti sehingga dalam waktu singkat diperoleh banyak data/keterangan. Berdasarkan bentuknya, pertanyaan yang terdapat didalam angket tersebut memuat pertanyaan terbuka maupun pertanyaan tertutup. Dalam penelitian ini menggunakan jenis skala jawaban yaitu skala likert. Bobot nilai atau skor pada setiap angket adalah sebagai berikut :

Tabel 5. Skor Alternatif Jawaban Angket

\begin{tabular}{|c|c|}
\hline Alternatif Jawaban & Skor Pertanyaan \\
\hline Sangat Setuju & 4 \\
\hline Setuju & 3 \\
\hline Kurang Setuju & 2 \\
\hline Tidak Setuju & 1 \\
\hline
\end{tabular}


Volume 2 Nomor. 2, Oktober 2017

P-ISSN : 2541-1179, E-ISSN : 2581-1711

OJS :http://journal.uin-alauddin.ac.id/index.php/instek/index

Email : instek@uin-alauddin.ac.id

\section{Perancangan Sistem}

Perancangan sistem dilakukan melalui tahapan analisis kebutuhan, Dimana perancangan ini akan dibagi menjadi beberapa bagian, yakni:

\section{Diagram Konteks}

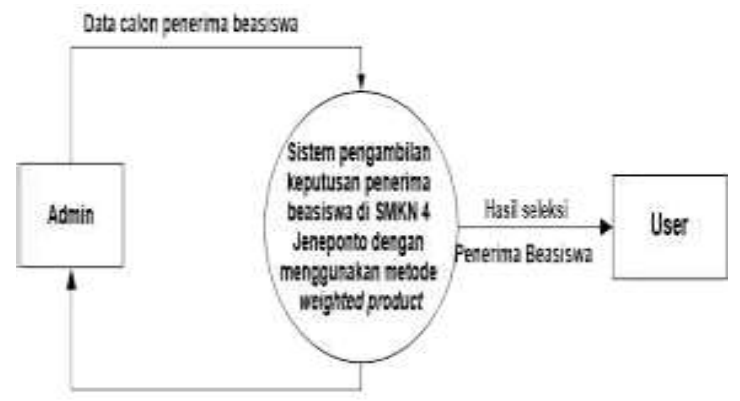

Laporn Paterima Bassisna

Gambar 2. Diagram Konteks

\section{Data Flow Diagram}

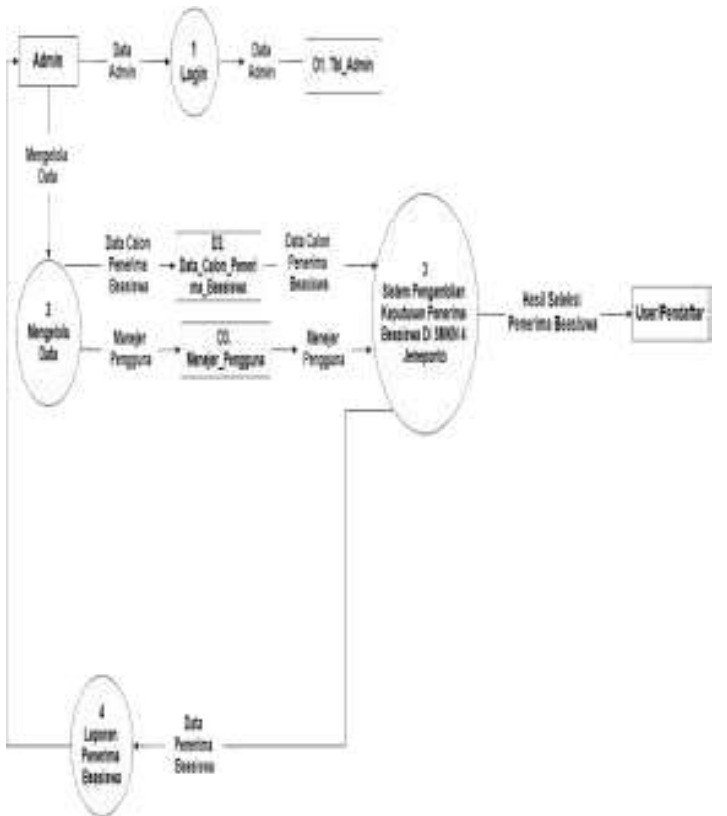

Gambar 3. Data Flow Diagram 
Volume 2 Nomor. 2, Oktober 2017

P -ISSN : 2541-1179, E-ISSN : 2581-1711

OJS :http://journal.uin-alauddin.ac.id/index.php/instek/index

INFORMATKKASANS DAN TEROLLOE

Email : instek@uin-alauddin.ac.id

\section{IV.HASIL DAN PEMBAHASAN}

\section{A. Implementasi Sistem}

Implementasi aplikasi sistem pengambilan keputusan penerima beasiswa terdiri dari beberapa form yang setiap form memiliki fungsi tersendiri. Form-form tersebut akan tampil sesuai dengan aktifitas yang dilakukan oleh pengguna dan urutan yang telah terprogram yaitu:

1. Form Login Admin

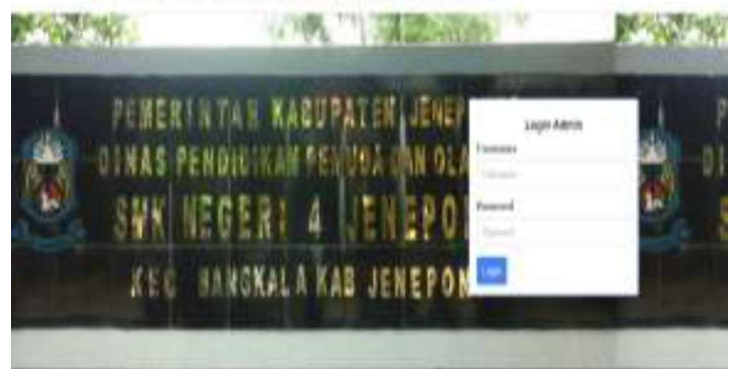

2. Home

Gambar 4. Form Login Admin

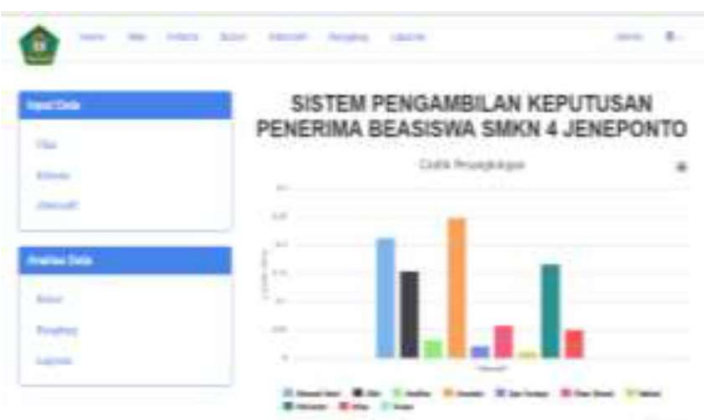

Gambar 5. Home

3. Halaman Nilai

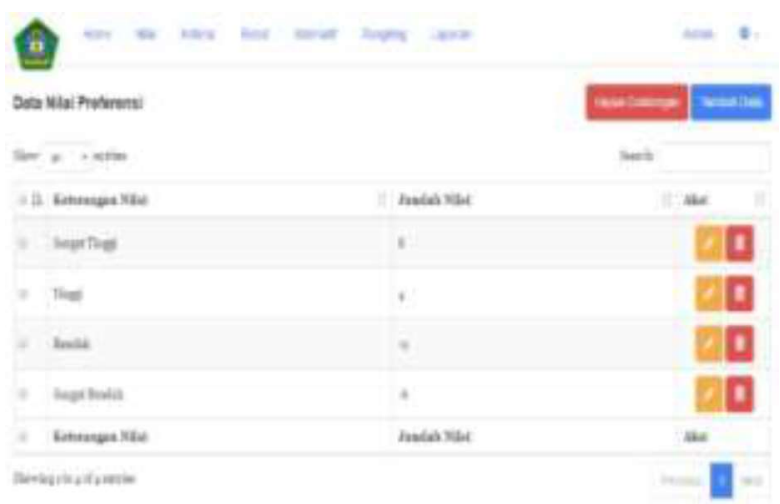

Gambar 6. Halaman Nilai 
Volume 2 Nomor. 2, Oktober 2017

P-ISSN : 2541-1179, E-ISSN : 2581-1711

OJS :http://journal.uin-alauddin.ac.id/index.php/instek/index

Email : instek@uin-alauddin.ac.id

4.Halaman Kriteria

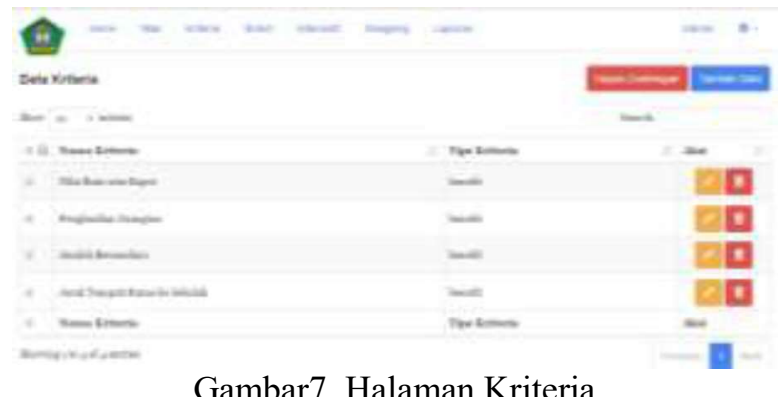

\section{Halaman Rangking}

Merupakan data perangkingan dari siswa yang behak menerima beasiswa

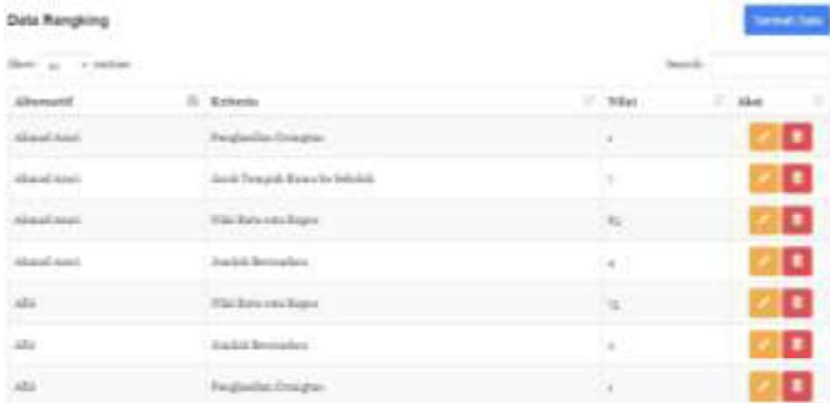

Gambar 8. Halaman Rangking

\section{Halaman Laporan}

Merupakan halaman nilai alternatif kriteria yang menentukan hasil seleksi.

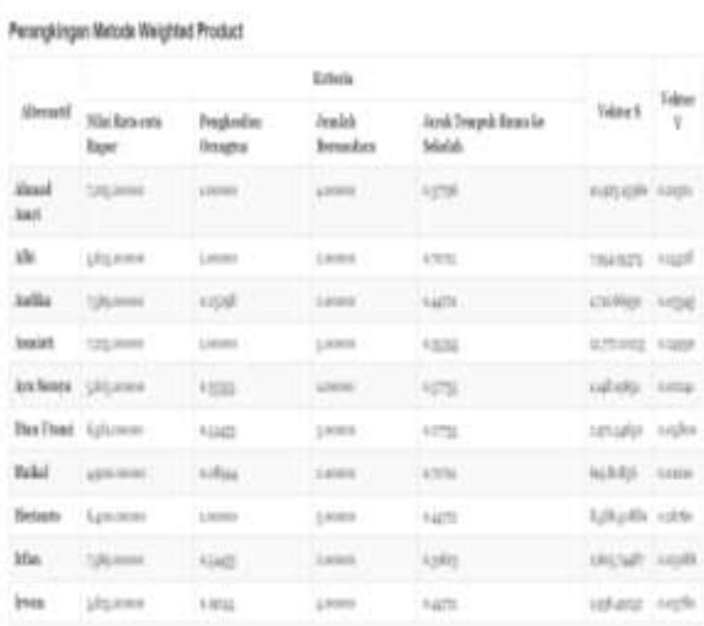

Gambar 10. Halaman Laporan 
Volume 2 Nomor. 2, Oktober 2017

P -ISSN : 2541-1179, E-ISSN : 2581-1711

OJS :http://journal.uin-alauddin.ac.id/index.php/instek/index

Email : instek@uin-alauddin.ac.id

\section{B. Hasil Pengujian}

Uji coba sistem ini dimaksud untuk menguji dan mengkaji seluruh elemen perangkat lunak yang telah peneliti, apakah sesuai dengan yang diharapkan. Berikut ini hasil pengujian aplikasi menggunakan Pengujian ISO 9126.

\section{Faktor Kualitas Functionality}

Pengujian faktor kualitas functionality dalam penelitian ini menggunakan metode black box testing.

Tabel 1. Hasil Pengujian Kualitas

\begin{tabular}{|c|l|c|}
\hline No & \multicolumn{1}{|c|}{ Deskrpsi } & Kesimpulan \\
\hline 1 & $\begin{array}{l}\text { Admin Melakukan } \\
\text { proses Login untuk } \\
\text { masuk ke menu admin }\end{array}$ & Berhasil \\
\hline 2 & Menambah data admin & Berhasil \\
\hline 3 & Mengedit data admin & Berhasil \\
\hline 4 & Menghapus data admin & Berhasil \\
\hline 5 & Mencetak data admin & Berhasil \\
\hline 6 & $\begin{array}{l}\text { Memperbaharui data soal } \\
\text { analisa }\end{array}$ & Berhasil \\
\hline 7 & Mengedit data user & Berhasil \\
\hline
\end{tabular}

\section{2.. Faktor Kualitas Usability}

Faktor kualitas Usability yang digunakan dalam penelitian adalah hasil penilaian dari responden dan validasi system.

Tabel 11. Distribusi Frekuensi Responden Angket Terhadap Sistem Pengambilan Keputusan Penerima Beasiswa

\begin{tabular}{|c|c|c|c|}
\hline Kategori & Interval & Frekuensi & Peresentase \\
\hline $\begin{array}{l}\text { Sangat } \\
\text { Setuju }\end{array}$ & $68-85$ & 7 & $70 \%$ \\
\hline Setuju & $\begin{array}{c}55,1- \\
67,9\end{array}$ & 3 & $30 \%$ \\
\hline $\begin{array}{l}\text { Ragu- } \\
\text { Ragu }\end{array}$ & $\begin{array}{c}42,4- \\
55\end{array}$ & 0 & $0 \%$ \\
\hline $\begin{array}{l}\text { Tidak } \\
\text { Setuju }\end{array}$ & $\begin{array}{c}29,7- \\
42,3\end{array}$ & 0 & $0 \%$ \\
\hline $\begin{array}{l}\text { Sangat } \\
\text { Tidak } \\
\text { Setuju }\end{array}$ & $\begin{array}{l}17- \\
29,6\end{array}$ & 0 & $0 \%$ \\
\hline \multicolumn{2}{|c|}{ TOTAL } & 10 & $100 \%$ \\
\hline
\end{tabular}


Volume 2 Nomor. 2, Oktober 2017

P -ISSN : 2541-1179, E-ISSN : 2581-1711

OJS :http://journal.uin-alauddin.ac.id/index.php/instek/index

INFORIATIKASANS DAN TERNOLOG

Email : instek@uin-alauddin.ac.id

\section{PEMBAHASAN}

Perancangan aplikasi sistem pengambilan keputusan penerima beasiswa di SMKN 4 Jeneponto menggunakan metode Weighted Product. Weighted Product adalah metode penyelesaian dengan menggunakan perkalian untuk menghubungkan reting atribut, dimana reting harus dipangkatkan terlebih dahulu dengan bobot atribut yang bersangkutan Inti dari metode WP yaitu untuk menentukan nilai bobot dari setiap kriteria, selanjutnya akan melalui proses penyaringan yang akan menyeleksi alternatif yang telah diberikan.

Aplikasi ini menggunakan pengujian ISO 9126, yang dimana pengujian ini dilakukan dengan menguji aplikasi dengan 6 faktor kualitas yaitu functional, reliability yaitu mengukur dengan cara mengamatji kestabilan penggunaan aplikasi pada saat user melakukan proses analisa, efficiency adalah melakukan pengujian berulangkali terhadap aplikasi, maintainability adalah menguji perangkat lunak pada beberapa aspek, portability menjalankan aplikasi di hardware yang berbeda dan usability adalah hasil penilaian dari responden dan validasi sistem. Selain menggunakan pengujian ISO 9126 , aplikasi ini juga telah diuji dan divalidasi oleh ahli yang berkompeten dibidangnya. Hasil pengujian validator 1 dan validator 2 menunjukkan jumlah skor 39 pada validator pertama dan 19 pada validator kedua dan termasuk kategori baik.

\section{KESIMPULAN}

a. Berdasarkan hasil perancangan dan pengujian sistem pengambilan keputusan penerima beasiswa di SMKN 4 Jeneponto menggunakan metode Weighted Product dapat disimpulkan bahwa sistem yang telah dirancang tersebut merupakan sebuah alternatif dalam meningkatkan keefisienan pendaftaran dan penyeleksian penerima beasiswa di SMKN 4 Jeneponto.

b. Aplikasi sistem pengambilan keputusan ini memiliki enam menu utama yaitu menu home, menu nilai, menu bobot, menu kriteria, menu perangkingan dan laporan hasil seleksi penerima beasiswa yang berfungsi untuk menyeleksi siswa yang memenuhi syarat untuk menerima beasiswa.

c. Pengujian ini menggunakan uji kelayakan perangkat lunak ISO 9126 yang dimana pengujian tersebut meliputi 6 aspek yakni, functionality, realibility, efficiency, maintainability, portability dan usability, adapun hasil pengujian dengan menggunakan ISO 9126 yaitu untuk faktor kualitas functionality seluruh tombol pada aplikasi dapat berfungsi dengan baik. 
Volume 2 Nomor. 2, Oktober 2017

P -ISSN : 2541-1179, E-ISSN : 2581-1711

OJS :http://journal.uin-alauddin.ac.id/index.php/instek/index

INFORIATIKASANS DAN TERNOLOGI

Email : instek@uin-alauddin.ac.id

d. Berdasarkan hasil ujicoba faktor kualitas Usability dengan menggunakan hasil penilaian dari responden dan validator sistem serta validator instrument. Adapun hasil dari penilaian responden yaitu $70 \%$ responden yang menjawab pernyataan sangat setuju dan $30 \%$ responden yang menjawab setuju. Kemudian hasil penilaian dari validator yakni untuk penilaian validasi sistem, diperoleh hasil sistem berada pada kategori baik.

\section{DAFTAR PUSTAKA}

Abdillah, Leon Andretti. Sistem Pendukung Keputusan Pemberian Beasiswa Bidik Misi. Universitas Bina Darma, Palembang.

Davis, Ralp C dalam Hasan. 2004. Pokok-pokok Materi Teori Pengambilan Keputusan. Jakarta: Gralia Indonesia.

Diah, Ardi Kusumaning, dkk. 2013. Sistem Pendukung Keputusan Penerimaan Beasiswa Di SMA N 1 Brebes Dengan Metode Fmadm Dengan Metode Saw. Universitas Dian Nuswantoro, Semarang.

Eko Wahyu Prasetyo. 2012. Sistem Pendukung Keputusan Seleksi Penerima Beasiswa Pada Smk Bina Nusantara Ungaran Menggunakan Metode Analithical Hierarchi Process (Ahp). Program Studi Sistem Informasi, Fakultas Ilmu Komputer Universitas Dian Nuswantoro. Semarang

Endang, Mulayaningsih. 2011. Riset Terapan Bidang Pendidikan dan Teknik. Yogyakarta: UNY Press.

Gafur. 2013. Perancangan Sistem Pendukung Pengambilan Keputusan Seleksi Penerima Beasiswadengan Metode Multi Attributedecision Making (MADM). Unhas, Makassar.

Kusumaningrum, Mutsani. 2014. Aplikasi Sistem Pengambil Keputusan Penerima Beasiswa Untuk Santri di Pondok Pesantren Modern Imam Syuhodo. Skripsi tidak di terbitkan. Surakarta: Program Studi Teknik Informatika Fakultas Komunikasi Dan Informatika Universitas Muhammadiyah Surakarta.

Rosyidah, Umi , 2007, Model penaksiran respon emosi berdasrkan warna menggunakan metode simple additive weighting (SAW), Teknik elektro, Institut Teknologi sepuluh nopember, Surabaya

Sugiyono. 2009. Metode Penelitian Pendidikan Pendekatan Kuantitatif, Kualitatif, dan R \& D. Bandung: Alfabeta.

Syaukani, Guritno, 2013. Fuzzy simple additive weighting untuk diagnosis penyakit pneumonia, jurnal buana informatika, Universitas Admajaya Yogyakarta 